\title{
Extraction and assessment of pectin from pumpkin peels
}

\author{
AWADIA ALDOW RAMADAN HAMED ${ }^{1}$, SALMA ELGHALI MUSTAFA ${ }^{2, \bullet}$ \\ ${ }^{1}$ College of Graduate Studies, Sudan University of Science and Technology. Khartoum, Sudan \\ ${ }^{2}$ Department of Food Science and Technology, College of Agricultural Studies, Sudan University of Science and Technology. Khartoum, Sudan. \\ vemail: salma-a@sustech.edu
}

Manuscript received: 2 October 2017. Revision accepted: 26 December 2017.

\begin{abstract}
Hamed AAR, Mustafa SE. 2018. Extraction and assessment of pectin from pumpkin peels. Biofarmasi J Nat Prod Biochem 16: 1-7. Pectin is characterized as intricate blends of polysaccharides that compose around 33\% of most plants' cell wall dry substance. This study was done to extricate pectin from a completely ripened pumpkin (Cucurbita spp.) using two distinct techniques; the soxhlet acid extraction technique and acid extraction technique, and to find out the impact of utilizing distinctive acids on the yield of pectin; nitric and citric acids were utilized. In addition, to analyze the impact of time on pectin yield, the extraction procedure was carried out using 3 different times, namely, 30, 60, and $90 \mathrm{~min}$. The chemical substances of pumpkin peel (dampness, ash, protein, fat, fiber, total sugar, and calcium) and the chemical properties of pectin (methoxyl content, acetyl content, identical weight, and level of esterification) were extracted with both nitric and citric acids were also identified. The outcomes produced by the soxhlet acid extraction technique and acid extraction technique were $7.72 \%$ nitric acid and $6.80 \%$ citric acid and $6.24 \%$ nitric acid, and 5.36\% citric acid, respectively, demonstrating that the utilization of soxhlet acid extraction technique with nitric acid got the highest yield of pectin. Additionally, it was also discovered that the time for pectin extraction was $60 \mathrm{~min}$ at the very most. The outcome for the chemical substances of pumpkin peel (dampness, fiery remains, protein, fiber, fats, add up to sugar, and calcium) were 20.1, 7.1, 3.2, 10.15, 2.3, 57.15, and 0.308\%, respectively. The examination discovered that the chemical properties of pectin extracted with both nitric and citric acid were for the equivalent weight $(1250$ and $1250 \mathrm{~g} / \mathrm{mol})$, methoxyl content $(6.20$ and $6.29 \%)$, acetyl contains $(0.43$ and $0.43 \%)$ and the level of esterification $(66.53$ and $66.57 \%)$ respectively. The outcome got from this examination showed that pectin extracted from pumpkin peel is of high quantity and quality and is promising for commercial production.
\end{abstract}

Keywords: Cucurbita, pectin, pumpkin peels

\section{INTRODUCTION}

Pumpkins belong to the gourd family Cucurbitaceae, containing watermelons, cucumbers, gourds, marrow, and squash (Elshafie 1981). Cucurbits consist of 110 genera, and 640 species predominate in the tropics, mostly as herbs of very rapid growth and climbing habit with abundant sap (Trease and Evans 1989). Pumpkin is rich in polysaccharides, carotene, mineral salts, vitamins, and other substances beneficial to health, resulting in various processed food products being developed (Ptichkina et al. 1998).

Ordinarily, fruits are productized into juice, beverage, squash, and syrups. During productizing, peel presents almost $5-20 \%$ of the whole fruit. Therefore, the vast sum of by-products (55-60\% peel and 5-10\% seed) has contributed to the pollution of the environment. Nevertheless, byproducts can be utilized as functional food components such as photochemical, pharmaceuticals, food products, essential oils, seed oil, pectin, and dietary fibers. Therefore, by-products are considered to be rich sources of edible and health-promoting agents (Ali, 2014).

Pumpkin is also a low-cost source of pectin (Murkovic et al. 2002). Pectin is an abundant multifunctional component in the cell walls of all plants (Willats et al., 2006; Ngouémazong et al., 2012). Pectin is a polysaccharide consisting mostly of polymers rich in galacturonic acid, containing significant amounts of rhamnose, arabinose, galactose, and 13 monosaccharides (Vincken et al. 2003). Waldron et al. (2003) reported that pectin's composition, structure, and physiological properties could be influenced by extrication conditions, source, location, and many other environmental factors. Therefore, the network of pectin must be broken to be extracted.

Pectins are regularly extracted from citrus fruits and apple pomace, and they are customarily utilized as gelling agents for jams and marmalades. In combination with water and other substances, it can act as a thickener, gelling agent, stabilizer, emulsifier, cation-binding agent, etc. (Bottger 1990). Once a substance has so many properties of technological interest, this makes pectin a biopolymer especially valuable for medicine, food production, and applications in drug encapsulation (Ptichkina et al., 2008; Souza et al., 2009; Benjamin et al., 2012).

The objectives of this study were: (i) To determine the chemical composition of pumpkin peels (moisture, protein, ash, fat, fiber, total sugar, and calcium), (ii) To investigate the effect of different extraction methods (soxhlet acid extraction method and acid extraction method) with different acids (nitric and citric acids) in yield of pectin, (iii) To examine the effect of time on pectin yield, (iv) To evaluate the properties of the extracted pectin. 


\section{MATERIALS AND METHODS}

\section{Materials}

Pumpkin peels

Pumpkin was achieved directly from the local central market for fruits and vegetables in North Khartoum, Sudan was then stripped manually using a knife, baked at $70 ; 49^{\circ} \mathrm{C}$ for $24 \mathrm{~h}$ in an oven and ground, and kept for further analysis.

\section{Chemicals:}

In this study, all chemicals and reagents were of analytical grade. Nitric acid, hydrochloric acid, sulphuric acid, and boric acid are from SDFCL Sd Fine Chem Ltd. (Mumbai, India). Sodium hydroxide, citric acid, methyl red, phenol red, and catalyst tablet were from Lobach Emie Pvt. Ltd. (Mumbai, India). Petroleum ether is from Alpha Chemical (India), Magnesium sulphate is from Landcech Chemical (India), while Sodium chloride is from Scharlaau (Spain), and ethanol is from Drummer and Sons, Co. Ltd. (Sham Industrial City, Syria).

\section{Instruments}

Soxhlet, protein unit, ovens, $\mathrm{pH}$ meter, and centrifuge are from J.P Selecta (Spain), water bath from Daiham Scientific, Co., Ltd. (South Korea), and thermometer (Omsons, India).

\section{Methods}

Analysis of the chemical composition of pumpkin peels

Moisture content. The AOAC method (1999) was used to consider the moisture content. Samples $(5 \mathrm{~g})$ were accurately weighed and dried to constant weight in a vacuum oven at $70^{\circ} \mathrm{C}$ and $450 \mathrm{~mm} \mathrm{Hg}$ for three hours. The analysis was carried out in triplicate.

$$
\begin{aligned}
& \text { Moisture\% }=(\mathrm{W} 1-\mathrm{W} 2) / \mathrm{S} \\
& \text { Whereas: } \\
& \text { W1 : weight before drying } \\
& \text { W2 : weight after drying } \\
& \mathrm{S} \text { : weight of the sample. }
\end{aligned}
$$

Ash content. AOAC (1999) method was used to consider the ash content. Samples (5 g) were accurately weighed and put into relatively broad crucibles that had been ignited, then they were cooled in desiccators and weighed. The crucible and its content were ignited in a muffle furnace at $550{ }^{\circ} \mathrm{C}$ until light grey ash of samples with constant weight was obtained. The analysis was carried out in triplicate samples.

The ash content was calculated as follows:

$$
\operatorname{Ash} \%=\mathrm{W}_{1}-\mathrm{W}_{2} / \mathrm{W}_{1}-\mathrm{W}_{0}
$$

\section{Whereas:}

$\mathrm{W}_{0}$ : weight of the empty crucible

$\mathrm{W}_{1}$ : weight before ash processing

$\mathrm{W}_{2}$ : weight after ash processing

\section{Protein content}

The determination of Nitrogen content was done with the semi-micro Kjeldahl distillation according to AOAC (1999) method. An exact $0.2 \mathrm{~g}$ of the sample was assimilated in a small digestion flask using a half tablet of catalyst (each tablet contains $1 \mathrm{~g}$ anhydrous sodium sulphate and $0.1 \mathrm{~g}$ copper sulphate). $3.5 \mathrm{~mL}$ of concentrated sulphuric acid was added to it. Then the digest was diluted and transferred to the ammonia distillation apparatus using the minimum volume of distilled water and made alkaline with $20 \mathrm{~mL}$ of $40 \%$ sodium hydroxide. The ammonia was distilled into $2 \%$ boric acid solution $(10 \mathrm{~mL})$, plus methyl red indicator (3-4 drops) for 5-10 minutes. After lowering the receiving flask clear of the condenser, the apparatus was steam distilled for 5 minutes. The distillate was then titrated with $0.02 \mathrm{~N}$ hydrochloric acid.

$\mathrm{N} \%=\underline{(\mathrm{m} 1 \mathrm{HCL}-\mathrm{m} 1 \mathrm{blank}) \times \text { normality of HCL } \times 14 \times 100}$ sample ( $\mathrm{mg})$

Crude protein $=\% \mathrm{~N} \times 6.256 .25=$ refer to formula of protein

Fats content. The estimation of fat content was done using the method of AOAC (1999). Triplicate samples (2 g) were weighed and put into a thimble plugged with a piece of cotton wool. The thimble was then put into a soxhlet extractor. A dry and accurately weighed soxhlet flask was fitted to the extractor. Boiling petroleum with a temperature range of $60-80{ }^{\circ} \mathrm{C}$ was poured into two-thirds of the flask. The instrument was then set up and fitted to the condenser. Water was allowed to flow through the condenser, and an electric heater was put on for reflux. The extraction was done for eight hours. Then the instrument was carefully disassembled, and the liquid in the flask was evaporated to dryness in an oven at $100{ }^{\circ} \mathrm{C}$ to a constant weight.

$$
\text { Fat } \%=\frac{\text { the weight of ether extract } \times 100}{\text { Weight of sample }}
$$

Fiber content. AOAC (1999) method was used to estimate the fiber content. The sample from the ether extract was air-dried and transferred to a dry conical flask. Then $200 \mathrm{~mL}$ of $1.25 \%$ sulphuric acid boiled within one minute were added, and the mixture then was boiled gently for 30 minutes; constant volume was maintained, and the flask was shaken every few minutes. The residue was then filtered through apices of cotton fitted to the Buchner funnel. The filtration of the solution was completed within 10 minutes. The insoluble matter was washed with hot water until it was free from acid. It was then washed back into the original flask by a washing bottle containing $1.25 \%$ sodium hydroxide $(200 \mathrm{~mL})$ measured at room temperature and brought to boiling. It was allowed to boil for 30 minutes, filtered immediately through an ash-less filter paper, and then washed with $1 \% \mathrm{HCL}$, followed by boiling water until it was free from acid. The residue was transferred to a dried weight crucible and dried at $100^{\circ} \mathrm{C}$ to reach constant weight. The residue was finally ashed at $600^{\circ} \mathrm{C}$ in a muffle furnace. The weight of the ash was 
subtracted from the weight of the dish plus insoluble residue before ashing, and the difference was expressed as crude fiber percentage.

Carbohydrate content. It was estimated according to the method of AOAC (1999).

Carbohydrate $\%=100-($ moisture + ash + protein + fat and fiber\%).

Calcium content. The method described by Elmer (1993) was used to determine the content of Calcium. One gram of the material was put in a porcelain crucible, placed in a cool muffle furnace, and ashed at $500{ }^{\circ} \mathrm{C}$ overnight. The crucible content was dissolved into $5 \mathrm{~mL}$ of $25 \% \mathrm{HCL}$. The solution was warmed to dissolve the residue and filtered through an acid-washed filter paper in a $50 \mathrm{~mL}$ volumetric flask. The filter paper was washed; the solution was diluted with distilled water to volume and mixed well. Using one milliliter of this solution, the amount of calcium was spectrophotometrically determined at a wavelength of $422.7 \mathrm{~nm}$ using an Atomic Absorption spectrophotometer (AA-6800, Japan).

\section{Pectin extraction method}

The extraction method is referred to as the method by Malviya (2010). It can be carried out in two steps.

Pectin extraction. Pectin was extracted under reflux in a condensation system using water which was acidified for $1 \mathrm{hr}$ with acid to $\mathrm{pH} 2$. The temperature of extraction media was maintained at $80^{\circ} \mathrm{C}$, and extraction time was adjusted to about $6 \mathrm{~h}$. Whatman cellulose thimble with $33 \mathrm{~mm}$ of internal diameter and $80 \mathrm{~mm}$ of external length was used as an extractor thimble. Dried powdered pumpkin peel was taken in Soxhlet, and reflux was continued for $6 \mathrm{~h}$.

Pectin precipitation. Hot acid extract was pressed into a cheesecloth bag, and the cake was cooled to $4{ }^{\circ} \mathrm{C}$. Pectin was precipitated by alcohol treatment $2: 1(\mathrm{v} / \mathrm{v})$, followed by continuous stirring for $15 \mathrm{~min}$, and allowed to stand for $2 \mathrm{~h}$ for better precipitation. This allowed the filtering of pectic substances because pectin remained floating on the surface of alcohol. Floating pectin coagulate was filtered through a cheesecloth, washed with alcohol 70\%, and pressed. Pressed pectin was dried to constant weight at 35$45^{\circ} \mathrm{C}$ in a hot oven. Hard pectin cake was ground and sieved through a 20 mesh size sieve and, at last, was stored in a desiccator for further use.

Acid extraction method. According to Crandall et al. (1978), the method for acid extraction has some modifications. Four hundred $\mathrm{mL}$ of distilled water (DW) was poured into a $2000 \mathrm{~mL}$ Erlenmeyer flask and kept at the desired temperature, i.e., $80{ }^{\circ} \mathrm{C}$, using the stirring hot plate or the shaking water bath, and $100 \mathrm{~g}$ peel was added to the water. Measured amounts of acid using different acids (Nitric and Citric Acids) were added to the peel-water mixture until the desired $\mathrm{pH}$ was 2 . The mixture was stirred at a constant temperature until the desired extraction time had elapsed. The $\mathrm{pH}$ and temperature were recorded, and the mixture was allowed to cool in ice water until it reached $55{ }^{\circ} \mathrm{C}$. The mixture was then centrifuged at 5050 rpm for $10 \mathrm{~min}$. The filtrate was vacuum filtered using filter paper, and the solids were resuspended in $400 \mathrm{~mL}$ of $60{ }^{\circ} \mathrm{C} \mathrm{DW}$ water for $5 \mathrm{~min}$. Acid extracted pectin was kept after overnight precipitation. The pectin was separated from the alcohol solution using a double layer of cheesecloth, and the samples were washed three times with $70 \%$ diluted alcohol to remove any impurities. The resulting pectin was dried under vacuum at $50{ }^{\circ} \mathrm{C}$ in aluminum sample dishes until all moisture was removed. Pectin was cooled, weighed, and ground using a mortar and pestle. Ground pectin was stored in small plastic sample bags. Both two extraction procedures were done twice using nitric and citric acids. The amount of pectin was calculated according to the following equation:

$$
\text { Pectin yield }=\frac{\text { Weight of extracted pectin } \times 100}{\text { Weight of dried peel }}
$$

\section{Effect of time in pectin extraction}

The effect of time on pectin yield was examined to determine whether increasing extraction time will increase pectin yield. The extraction time was set at 30, 60, and 90 min; the extraction time followed the method by Crandall et al. (1978), with little modification. Effect of time on acid extracted pectin yield was done at extraction conditions of $80^{\circ} \mathrm{C}, \mathrm{pH} 2$ using $1 \mathrm{~N}$ nitric acids, and solid to liquid ratio of $1: 4 \mathrm{~g} / \mathrm{mL}$ using a water bath.

\section{Chemical analysis of extracted pectin}

Moisture content. The method of AOAC (1995) was used to determine the moisture content of pectin. Triplicate samples $(1 \mathrm{~g})$ were weighed in dried and weight aluminum dishes. Samples were then dried for 4 hours at $105{ }^{\circ} \mathrm{C}(20$ $\mathrm{mmHg}$ ). They were then cooled in desiccators, and their constant weights were determined. The moisture content was calculated as follows:

$$
\text { Moisture } \%=\left(\mathrm{W}_{1}-\mathrm{W}_{2}\right) / \mathrm{S}
$$

Whereas:

W1 : weight before drying.

W2 : weight after drying.

$\mathrm{S}$ : weight of the sample.

Ash content. The AOAC (1995) method was used to determine the ash content of pectin. Triplicate samples (1 g) were previously weighed, then heated, cooled, and weighed their crucible weight. The sample was then heated at $600{ }^{\circ} \mathrm{C}$ for 3 hours, cooled, and determined constant weight. The ash content was calculated as follows:

$\operatorname{Ash} \%=\mathrm{W}_{1}-\mathrm{W}_{2} / \mathrm{W}_{1}-\mathrm{W}_{0}$

Whereas:

$\mathrm{W}_{0}$ : weight of empty crucible.

$\mathrm{W}_{1}$ : weight before ashing

$\mathrm{W}_{2}$ : weight after ash

Ash alkalinity. The method by Owens et al. (1952) was used to determine the ash alkalinity of pectin. The ash was dissolved in $25 \mathrm{~mL}$ of $0.1 \mathrm{~N} \mathrm{HCL}$, heated gently, and then 
titrated with $0.1 \mathrm{~N}$ sodium hydroxide using a phenolphthalein indicator. The alkaline number of ash was calculated as the number of a millimeter of acid required to neutralize $1 \mathrm{~g}$ of ash.

Equivalent Weight. Ranganna's method (1995) was used to determine Equivalent weight. Triplicate samples $(0.5 \mathrm{gm})$ were weighed into a $250 \mathrm{~mL}$ conical flask and moistened with $5 \mathrm{~mL}$ ethanol. The product was mixed with $1 \mathrm{gm}$ sodium chloride and $100 \mathrm{~mL}$ of distilled water. The mixture was stirred vigorously, and free acidity was determined by direct titration against $0.1 \mathrm{~N}$ sodium hydroxide using phenol red as an indicator. Also, a blank containing the same quantities of reagents was tested. This titre is known as the initial titre (IT) or free acid titre. The equivalent weight was calculated as follows:

Equivalent weight $=$ weight of sample $(\mathrm{mg}) / \mathrm{Meg}$ of sodium hydroxide

Meq (Miliequivalent of sodium hydroxide $)=$ Normality $\times$ Titre volume of Noah

Methoxyl content. Ranganna's method (1995) was used to determine $\mathrm{MeO}$ content. The neutral solution was collected to determine the equivalent weight, then $25 \mathrm{~mL}$ of sodium hydroxide $(0.25 \mathrm{~N})$ was added. The mixed solution was stirred thoroughly and kept at room temperature for 30 min. After $30 \mathrm{~min}, 25 \mathrm{~mL}$ of hydrochloric acid $(0.25 \mathrm{~N})$ was added and titrated against $0.1 \mathrm{~N} \mathrm{NaOH}$.

The following formula calculated methoxyl content :

$$
\text { Methoxyl content } \%=\frac{\text { Meq of } \mathrm{NaOH} 3.1 \times 100}{\text { Weight of sample }}
$$

\section{Whereas:}

Meq of $\mathrm{NaOH}=$ normality of $\mathrm{NaOH}$ titre figure 3.1 refers to a formula weight of methoxyl group.

Degree of esterification (DE). Based on methoxyl content (Owens et al. 1952), the DE of pectin was measured

From IT and ST obtained, the degree of esterification and Anhydrouronic acid (AUA) content was calculated as follows:

Degree of esterification $(\mathrm{DE})=\mathrm{ST} \times 100 / \mathrm{ST}+$ Corrected IT The IT corrected the ash alkalinity

Acetyl content. Owens et al. (1952) method was used to determine Acetyl content. Triplicate samples ( $0.5 \mathrm{gm})$ of each pectic substance were weighed into a flask, and 250 $\mathrm{mL}$ of $0.1 \mathrm{~N} \mathrm{NaOH}$ were added. The flask was covered, shaken, and left for one night. The solution was then diluted to $50 \mathrm{~mL}$, from which $20 \mathrm{~mL}$ were taken and placed in the distillation apparatus. Twenty milliliter magnesium sulphate sulphuric acid solution (100 g magnesium sulphate and $1.5 \mathrm{gm}$ sulphuric acid diluted to $180 \mathrm{~mL}$ ) were added. The solution was then steam distilled, and $10 \mathrm{~mL}$ of distillate was collected. The acetic acid of the distillate was then titrated with sodium hydroxide $(0.05 \mathrm{~N})$ to phenol redpoint. The titre was corrected for the blank reagents.
The acetyl content (formula weight 43) of the sample was calculated according to the following equation:

Acetyl content $(\% \mathrm{w} / \mathrm{w})=\frac{(\mathrm{ml} \mathrm{NaOH})(\text { normality of } \mathrm{NaOH}) \times 43}{\text { Weight of sample }(\mathrm{gm}) \text { in the liquot }}$ Whereas:

$\mathrm{MI} \mathrm{NaOH}$ : volume required to titre distillate-volume of $\mathrm{NaOH}$ required to titre blank distillate run.

43 : formula weight of Acetylene.

\section{Statistical analysis}

Microsoft Excel software on the statistical page of social science was used to analyze the data of this study. Data were expressed as mean \pm standard deviation (STD). The statistical significance was considered at $P<0.05$. All experiments were organized using a completely randomized design with three replicates, repeated for reproducibility. The data obtained from the measurements were subjected to a T-test which was used to compare the difference between properties of pectin extracted by different acids. All measurements were carried out in triplicate for each sample. The experimental data were reported as the means \pm SD of independent trials (Wagner, 1985).

\section{RESULTS AND DISCUSSION}

\section{Chemical compositions of pumpkin peel}

Chemical compositions expressed on a dry basis were presented in Table 1 . The moisture content was $20.1 \%$. The Ash content of pumpkin peel was $7.1 \%$. The protein content of pumpkin peel was $3.2 \%$. The fiber content was $10.15 \%$. The fat content was 2.3. The carbohydrates of pumpkin peel were $57.15 \%$, and calcium was $0.308 \%$. This result was different from Ibrahim's study (2008), which found that the chemical compositions of pumpkin peel on a weight basis were as follows: the moisture content was 84.7-90.26\%; the Ash content of pumpkin peel was $0.81-1.35 \%$; the protein content of pumpkin peel was $1.3-1.64 \%$; the fiber content was $3.21-4.82 \%$; the content of fat, carbohydrates, and calcium were $0.04,5.17$ and $0.062 \%$ respectively.

Table 1. Chemical compositions of pumpkin peels on dray basis

\begin{tabular}{ll}
\hline Parameter & \% \\
\hline Moisture & 20.1 \\
Ash & 7.1 \\
Protein & 3.2 \\
Crud fiber & 10.15 \\
Fats & 2.3 \\
Carbohydrate & 57.15 \\
Calcium & 0.308 \\
\hline
\end{tabular}

Note: Values are means of 3 replicates for each parameter 


\section{Effect of different methods on pectin yield}

The optimal extraction conditions of this study used nitric and citric acid to adjust the $\mathrm{pH}$ of pumpkin peel to 2, which was then extracted for $60 \mathrm{~min}$ at $80^{\circ} \mathrm{C}$. Soxhlet extraction was done for six hours with alcohol precipitation for two hours, but in acid extraction without soxhlet, alcohol perception was ten hours. The results were $7.72 \%$ nitric acid and $6.80 \%$ citric acid using the soxhlet acid extraction method and $6.24 \%$ nitric acid and $5.36 \%$ citric acid using the no soxhlet acid extraction method. As shown in Figure 1, the result indicated that using the soxhlet acid extraction method gave a higher yield than using the acid extraction method without soxhlet to extract pectin from pumpkin peel. The result in this study was different from the result of the study by Yeoh et al. (2008). They showed that, for microwave extraction, the greatest total amount of pectin yield was $5.27 \%$ on a dry basis for 15 minutes of extraction. However, the greatest amount of material per unit time $(\% / \mathrm{min})$ was obtained after 5 minutes. This amount was the same as that result extracted by the Soxhlet extraction method for three hours from orange peel.

\section{Effect of different acids on pectin yield}

In this study, the extracted pectin from pumpkin peels was $6.24 \%$ using nitric acid and $5.36 \%$ using citric acid. The study showed that nitric acid yielded higher results than citric acid, respectively, as shown in Figure 1. A significant difference of $\mathrm{p} 0.05$ was found between the two acids. The result was higher than the range of 0.253 $0.233 \%$ for pectin extraction from alcohol insoluble pumpkin peel solids using hydrochloric acid to adjust $\mathrm{pH}$ to 2 and which was extracted for $60 \mathrm{~min}$ at $80^{\circ} \mathrm{C}$ (Ibrahim, 2008). It differed from Sayah et al. (2014), who extracted pectin from steam distillation and non-conditioned orange peels using different acids.

Citric acid gave the best average yield $(25.71 \% \pm$ 0.007 ), while sulfuric, hydrochloric, and acetic acids gave a very low average yield of pectin, namely $6.49 \% \pm 0.005$, $7.96 \% \pm 0.005$, and $10.19 \% \pm 0.006$, respectively.

\section{Effect of extraction time in pectin yield}

The effect of extraction time on pectin yield was observed to determine the effect of the extraction time on the increase of pectin yield. The results are shown in Figure 2. There was an increase in pectin yield during $30 \mathrm{~min}$ and $60 \mathrm{~min}$ of extraction time. Since there was no noticeable trend of pectin yield increase with extraction time from 60 min to $90 \mathrm{~min}$, so, the suitable extraction time was $60 \mathrm{~min}$. The result of this study disagreed with (Campbell 2006). There was increasing in pectin yield between $0-45 \mathrm{~min}$. No noticeable on-time trend occurred with increasing extraction time from $45 \mathrm{~min}$ to $90 \mathrm{~min}$.

\section{Chemical composition in pectin pumpkin peels Moisture content}

The moisture content of pectin pumpkin peels extracted by nitric and citric acids was $5.54 \pm 0.01 \%$ and $5.42 \pm 0.0 \%$, respectively, as shown in Figure 3. A significant difference of p0.05 was found between the two samples. The result is lower than the value of grapefruit peels pectin, with the range of 7.88-8.96\%, as claimed by Mohamed (1999). The values were also higher than mango pulp pectin, with the range of 5.03-5.04\%, as Abderahman (2002) reported.

\section{Ash content}

The Ash content of pumpkin peels pectin extracted with nitric and citric acids was $3.17 \pm 0.006$ and $2.96 \pm 0.006 \%$, respectively, as shown in Figure 4. There was a significant difference of $\mathrm{p} 0.05$ between the two samples. The result is higher than a lemon with the range of $1.56-1.65 \%$, an orange with the range of $0.81-4.83 \%$ in orange, or an apple with the range of $0.49-8.05 \%$, as stated by Abderahman (2002). Mohamed (1999) reported a range of $1.8 \%$ to $2.0 \%$ for grapefruit peels pectin.

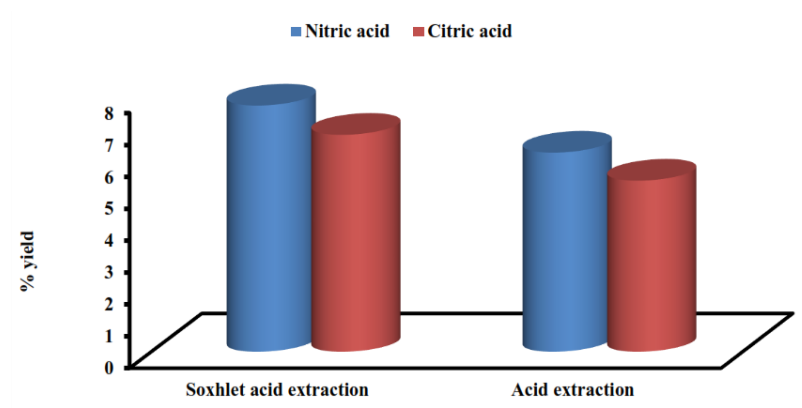

Figure 1. Pectin yield by using different methods and acid

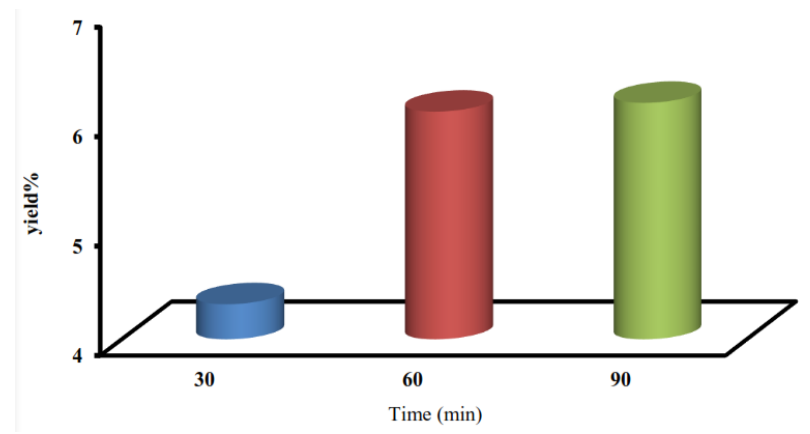

Figure 2. Effect of extraction time on pectin yield

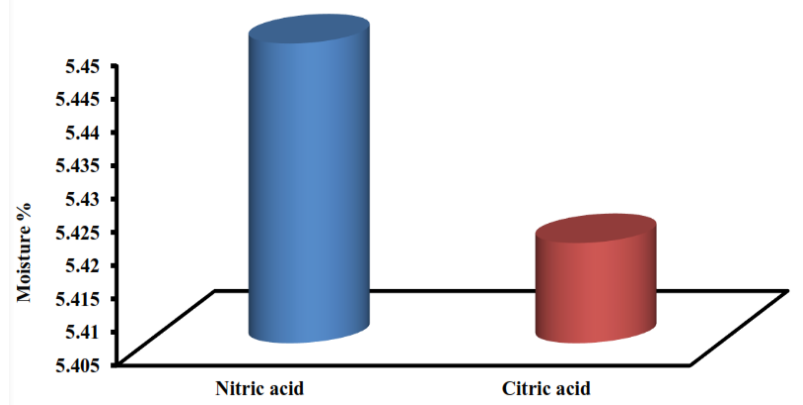

Figure 3. The moisture content of pectin in pumpkin peel 
The equivalent weight

The equivalent weights of extracted pectin from pumpkin peels, using nitric and citric acid, were $1250 \pm 0.0$ and $1250 \pm 0.0 \mathrm{~g} / \mathrm{mol}$, respectively, as shown in Figure 5 . The results showed no significant difference of p0.05 between the two samples. Still, they were higher than cocoa husk pectin $(510.68-645.19 \mathrm{~g} / \mathrm{mol})$, which was reported by Ramli and Asmawati (2011), and the ones reported by Mohamed (1999) for grapefruit peel pectin for citrus pectin $(620-749 \mathrm{~g} / \mathrm{mol})$. The equivalent weights obtained in this study were lower than, with a range of 1389-2003 g/mol (Abderahman 2002) or apple pomace pectin (833.33-1666.30 g/mol) (Kumar and Chauhan 2010) and ambarella peels $(263,000-303,000 \mathrm{~g} / \mathrm{mol}$ ) (Koubla 2008).

\section{Methoxyl content}

The methoxy1 contents of pumpkin peel pectin extracted by nitric and citric acids were $6.20 \pm 0.10 \%$ and $7.23 \pm 0.89 \%$, respectively, as shown in Figure 5. No significant difference p 0.05 was observed between the two samples. In this study, the methoxyl was lower than the one found by Ali (2014) for lemon pomace $(10.25 \pm 022 \%)$ and the one reported by Madhav and Pushpalatha (2002) for pomelo peel (8.57\%), Lime (9.92\%), passion (8.81-9.61\%); it was similar to peel of mango $(7.33 \%)$, banana $(7.03 \%)$ (Madhav and Pushpalatha, 2002) but it was higher than dragon fruit pectin (2.98\% to $4.34 \%$ ) (Ismail et al. 2012). Methoxyl content was an important factor in controlling pectin's setting time and the pectin's ability to form gels (Constenla and Lozano 2003).

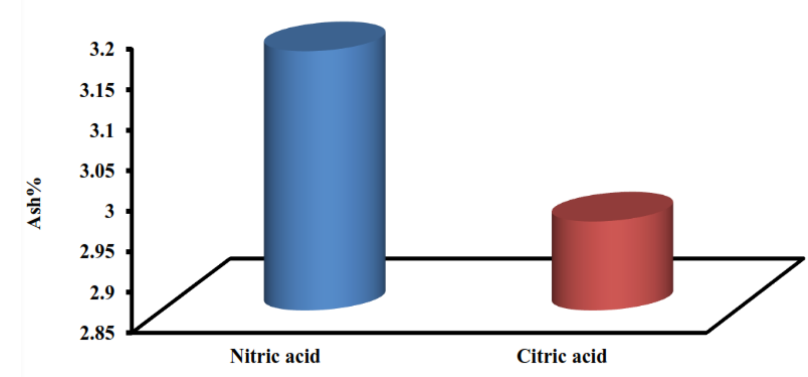

Figure 4. Ash content of pectin of pumpkin peel

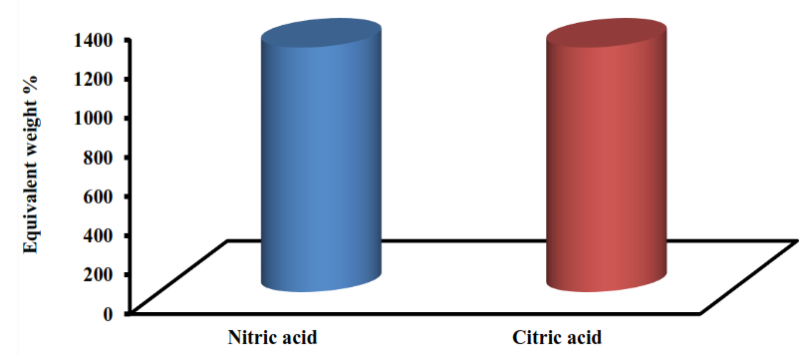

Figure 5. The equivalent weight of pectin of pumpkin peel

\section{Acetyl content}

The acety1 contents of pumpkin peel pectin extracted with nitric and citric acids were $0.43 \pm 0.01$ and $0.43 \pm 0.03 \%$, respectively (Figure 6). There was no difference of p0.05 between the two samples. The result was in accordance with the finding of Mohamed (1999), which showed that $0.46-1.63 \%$ for grapefruit peels pectin, and it was also higher than the result reported by Abderahman (2002) for acety1 content in mango pulp pectin $(0.117 \%$ to $0.314 \%)$. The acetyl group in pectin materials has an important role in their effect on the jelly formatting ability (Abderahman 2002). Also, the finding was lower than the one reported by Koubla et al. (2008) on amarelle peels, i.e., 4-6\%.

\section{Degree of esterification}

The results in Figure 7 showed the degree of esterification of pumpkin peels pectin extracted by nitric and citric acids were $66.53 \pm 0.058$ and $66.57 \pm 0.058 \%$, respectively.

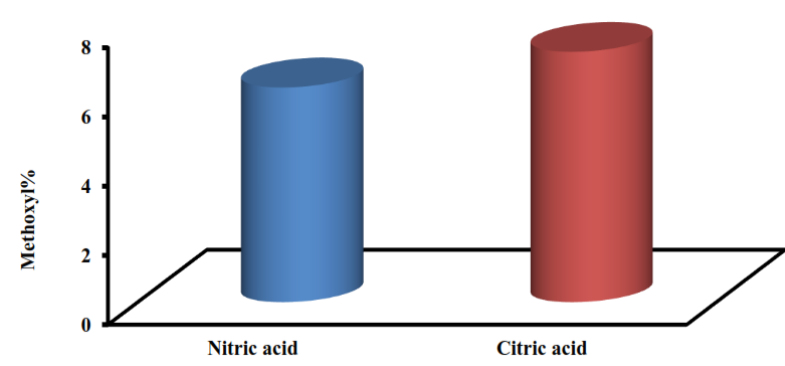

Figure 5. Methoxyl content of pectin of pumpkin peel

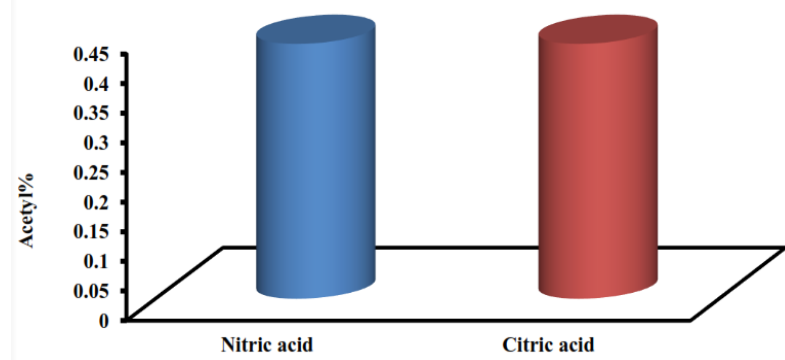

Figure 6. Acetyl content of pectin of pumpkin peel

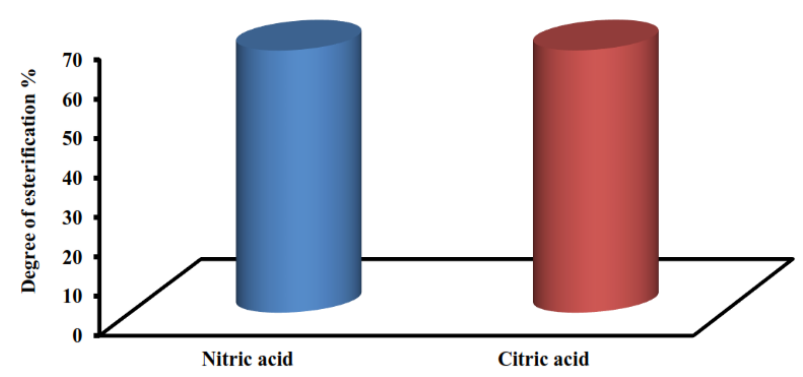

Figure 7. Degree of esterification of pectin of pumpkin peel 
There was no difference of $\mathrm{p} 0.05$ between the two samples. The result was in agreement with the result reported by Eltinay et al. (1982) for mango peel pectin $(66.9 \%)$ but higher than that obtained by Mohamed (1999) for grapefruit peels pectin, which was 51.01-51.24\% and by Koubla et al. (2008) for ambarella peels which were 50$58 \%$.

The values of degree in the esterification of this study were lower than those reported by Eltinay et al. (1982), Abderahman (2002), and Ali (2014) for pumpkin pectin (73.9-86.8\%), for mango pulp pectin $(87.0 \%)$ and lemon pomace pectin $(79.51 \pm 0.36$ and $70.39 \pm 4.20 \%)$ respectively. Pumpkin peel has a high level and good properties of pectin, and using Soxhlet, and nitric acid at $60 \mathrm{~min}$ for the extraction process gives the highest pectin yield.

\section{REFERENCES}

Abdelrahman NA. 2002. Characterization of Pectic Substance of AbuSamaka Cultivar in Relation to Their Influence on Mango Pulp Concentrates [Thesis]. University of Khartoum. Sudan.

Ali SM, Md Jiaur M. 2014. Isolation and Characterization of Pectin Extracted from Lemon Pomace during Ripening. J Food Nutr Sci 2 (2): 30-35.

AOAC. 1995. Official Methods of Analysis of the Association of Official Analytical Chemistry. 16th ed. AOAC International, Washington D.C., USA.

AOAC. 1999. Association of official Analytical chemists. 16th ed, Association of Official Analytical Chemists, Maryland.

Benjamin O, Silcock P, Leus M, Everett D W. 2012. Multilayer emulsions delivery systems for controlled release of volatile compounds using pH and salt triggers. Food Hydrocoll 27 (1): 109-118.

Bottger I. 1990. Pectin application-Some practical problems. In: Phillips GO, Wedlock DJ, Williams PA. (eds.). Gums and Stabilisers for the Food Industry. IRL Press, Oxford, UK.

Campbell M. 2006. Extraction of Pectin from Watermelon Rind. Oklahoma State University, Stillwater, Oklahoma

Constenla D, Lozano JE. 2003. Kinetic model of pectin demethylation. Latin American Appl Res 33: 91-96.

Crandall PG, Braddock RJ, Rouse AH. 1978. Determining the yield and quality of pectin from fresh peel and pectin pomace. Proc Florida State Hortic Soc 91: 109-11.

Elmer, MM. 1993. Characterization of apple fruit pectic substances. J Sci Technol 30 (2): 17-19.

Elshafie, AS. 1981. Isolation, Fractionation, and Characterization of Pumpkin Pectic Substance. [Thesis]. University of Khartoum, Sudan.

Eltinay AH, El Shafie AS, Nour AM. 1982. A chemical study of Pumpkin pectic substances. Faculty of Agriculture, University of Khartoum, Sudan.

Ibrahim, YA. 2008. Isolation and Characterization of Pectic Substance of pumpkin peels. [Thesis]. University of Khartoum, Sudan.

Ismail NSM, Ramli N, Hani NM, Meon Z. 2012. Extraction and characterization of pectin from dragon fruit (Hylocereus polyrhizus) using various extraction conditions. Sains Malaysiana 41: 41-45.

Koubla BB, Mbome TI, Kansci G, Tchouanguaeb Mbiapo F, Crepeau MJ, Thibault JF, Kallet MC. 2008. Chemical properates of pectin from ambarella peels (Spondias cytherea) obtain using different extraction condition. Food Chem 106: 1202-1207.

Kumar A, Chauhan, GS. 2010. Extraction and characterization of pectin from apple pomace and its evaluation as lipase (steapsin) inhibitor. Carbohydrate Pol 82: 454-459.

Madhav A, Pushpalatha PB. 2002. Characterization of pectin extracted from different fruit wastes. J Trop Agric 40: 53-55.

Malviya R, Srivastava P, Bansal M, Sharma PK. 2010. Mango peel pectin as super disintegrating agents. J Sci Industr Res 69: 688-690.

Mohamed HA. 1999. Extraction, Fraction, and Characterization of Pectic Substance of Grapefruit peels. [Thesis]. University of Khartoum, Sudan.

Murkovic M, Mülleder U, Neunteu H. 2002. Carotenoid content in different varieties of pumpkins. J Food Composit Anal 15: 633.

Ngouémazong DE, Tengweh FF, Fraeye I, Duvetter T, Cardinaels R, Loey AV, Moldenaers P, Hendrickx M. 2012. Effect of demethylesterification network development and nature of $\mathrm{Ca} 2+$-pectin gels: Towards understanding structureefunction relations of pectin. Food Hydrocoll 26: 89-98.

Owens HS, McCready RM, Shepherd AD, Schultz TH, Pippen EL, Swenson HA, Miers JC, Erlandsen RF, Macaly WD. 1952. Methods Used at Western Regional Research-Laboratory for Extraction and Analysis of Pectin Material. AIC 340. Albany, CA.

Ptichkina NM, Markina OA, Rumyantseva GN. 2008. Pectic extraction from Pumpkin with the aid of microbial enzymes. J Food Hydrocoll 22: 192-195.

Ptichkina NM, Novokreschonova LV, Piskunova GV, Morris ER. 1998. Large enhancements in loaf volume and organoleptic acceptability of wheat bread by small additions of pumpkin powder: Possible role of acetylated pectin in stabilizing gas-cell structure. J Food Hydrocoll 12: 333-337.

Ramli N, Asmawati. 2011. Effect of ammonium oxalate and acetic acid at several extraction time and $\mathrm{pH}$ on some physicochemical properties of pectin from cocoa husk (Theobroma cacao). African J Food Sci 5: 790-798.

Ranganna S. 1995. Hand Book of Analysis and Quality Control for Fruits and Vegetable Products. 2nd ed. McGraw Hill Publishing Co. Ltd., New Delhi.

Sayah MJ, Chabir R, El Madani N, Rodi El Kandri Y, Ouazzani Chahdi F, Touzani H, Errachidi F. 2014. Comparative study on pectin yield according to the state of the orange peels and acids used. Intl J Innov Res Sci Eng Technol 3 (8): 15658-15665.

Souza JRR, Carvalho JIX, Trevisan MTS, Paula RCM, Ricardo NMPS, Feitosa JPA. 2009. Chitosan-coated pectin beads: characterization and in vitro release of mangiferin. Food Hydrocoll 23 (8): 2278-2286.

Trease GE, Evans WC. 1989. Pharmacogsy. $13^{\text {th }}$ ed. Bailliere Tindall, London.

Vincken JP, Schols HA, Oomen RJFJ, Beldman G, Visser RGF, Voragen AGJ. 2003. Pectin-the hairy thing. In: Voragen AGJ, Schols H, Visser $\mathrm{R}$ (eds.). Advances in Pectin and Pectinase Research, Kluwer Academic Publishers, Boston.

Wagner AE, Meeker WQ Jr. 1985. Proceding of the Statistical Computing Section. Amer State Assoc., Washington, DC.

Waldron KW, Parker ML, Smith AC. 2003. Plant cell walls and food quality. Comp Rev Food Sci Food Saf 2: 101-119.

Willats WGT, Knox JP, Mikkelsen DJ. 2006. Pectin: new insights into an old polymer are starting to gel. Trends Food Sci Technol 17: 97.

Yeoh S, Shi J, Langrish T. 2008. A comparison between different techniques for water-based extraction of pectins from orange peels. Chem Eng Commun 19: 511-520. 